\title{
Development of a healthcare building sustainability assessment method - Proposed structure and system of weights for the Portuguese context
}

\author{
Maria de Fátima Castro*, Ricardo Mateus, Luís Bragança \\ Territory, Environmental and Construction Research Centre (CTAC), University of Minho, Campus de Azurém, 4800-048 Guimarães, Portugal
}

\section{A R T I C L E I N F O}

\section{Article history:}

Received 22 June 2016

Received in revised form

27 January 2017

Accepted 2 February 2017

Available online 5 February 2017

\section{Keywords:}

Building sustainability assessment methods

System of weights

Healthcare buildings

Life cycle assessment

\begin{abstract}
A B S T R A C T
In healthcare building projects, it is necessary to consider a larger number of different aspects than in other building types, as patients' emotions, comfort needs and the integration of latest technologies. To design these buildings, considering a sustainable approach, the sustainable practices for healthcare building should be considered properly in design and use phases.

Therefore, there is a lack of common understanding on the field of various relations between built, natural and social systems. To tackle this, the goal of this article is to contribute to the better understanding in this context by exposing a proposal for the structure and system of weights of the sustainability criteria of a healthcare building sustainability assessment method, the HBSAtool-PT. The methodological approach adopted is innovative since in the development of the list of sustainability criteria it considers the opinion of main healthcare buildings' stakeholders, the existing healthcare assessment methods and the ISO and CEN standardisation works in the field of the methods to assess the sustainability of construction works. Additionally, a methodology to develop the weighting system to be used in the aggregation of the different indicators is proposed and applied to the Portuguese context. As a result, the proposed sustainability assessment system for healthcare buildings (HBSAtool-PT) embraces fifty-two sustainability indicators that cover the different dimensions of the sustainability concept to support decision making during the design of a new or retrofitted healthcare building in urban areas. The proposed structure for the HBSAtool-PT presents a more balanced structure between the dimensions of the sustainable development, and compared with other existing approaches, it integrates more comprehensive social and economic concerns.
\end{abstract}

(C) 2017 Elsevier Ltd. All rights reserved.

\section{Introduction}

The following question was verbalised by Michael Lerner, in 2000: "The question is whether healthcare professionals can begin to recognise the environmental consequences of our operations and put our own house in order." (Brody, 2001) This question is not trivial, but the basis for all other concerns around the same issue (Roberts and Guenther, 2006). Regarding this principle, the connection between medical treatment, human health, and environmental pollution that affect the healthcare industry mission is known as the triple bottom line approach (Roberts and Guenther, 2006). It

\footnotetext{
* Corresponding author.

E-mail addresses: info@mfcastro.com (M.F. Castro), ricardomateus@civil. uminho.pt (R. Mateus), braganca@civil.uminho.pt (L. Bragança).
}

expresses the industry attitude to sustainable buildings and operations. So, healthcare organisations have been developing guidance documents and methodologies. For market success, the triple bottom line concept needs to consider: Environmental, Economic, and Social/Ethical performances.

At this level, it is important to demystify the common misunderstanding that the sustainable buildings cost is always greater than the costs of the other types of building. In this context, Cassidy (2003) concluded that many sustainable buildings cost no more than their brown (conventional) equivalents. Kats (2003) concluded with her study: great variation exists in buildings costs, even within the same building program type; and there are high-cost and low-cost sustainable and brown buildings.

At the same time that the strategist deals with the financial implications, the building occupants review the social impacts of 
sustainable building practices (Tsalis et al., 2015). Building occupants prioritise the relationship between buildings and health (Shaw et al., 2010). The current challenge in the healthcare sector is to assess the organisational and community benefits that result from sustainable building principles. These advantages must be quantified, defined and communicated to different stakeholders of the industry, and all the construction professionals have important roles in the construction process (Yadollahi et al., 2014). The seeker perspective is based on environmental leadership. Healthcare organisations strive to be leaders in sustainable building practices to (Roberts and Guenther, 2006): enhance their community and medical reputations; improve high standard staff recruitment and retention; and increase market share, philanthropy, and research grants.

In this context, regarding the massive consumption of energy and natural resources, healthcare buildings should be one of the most important studies in the life cycle assessment of the built environment (Guenther and Vittori, 2008). For instance, the activities developed inside the healthcare buildings consume a large amount of energy for cooling, heating and healthcare equipment operation. Additionally, the use of non-renewable and renewable resources, emissions of toxic substances, production of disposable products and the massive production of waste are important aspects to consider (Short and Al-Maiyah, 2009).

The healthcare sector that integrates a large and varied group of buildings, where the indoor environment quality is an aspect of major importance, and has a huge influence on the economy and policies of nations. Because these buildings are directly connected to human health, their impacts on Humans are very important (Guenther and Vittori, 2008).

Regarding the question "What makes a healthcare building sustainable?" there is no simple answer (Castro et al., 2014). That is because the concept of sustainability is not simply measurable.

To introduce sustainable practices in the healthcare buildings design, numerous countries, research centres and sustainability certification bodies have been publishing recommendations, guidelines and building sustainability assessment methods to promote improved design attitudes. At this level, it is significant to underline the recommendations, released by the Green Building Committee of the American Society for Healthcare Engineering (ASHE, 2002).

In the market, there are tools, such as the International Sustainable Building Tool (SBTool) (iiSBE, 2016), developed by the International Initiative for a Sustainable Built Environment (iiSBE) that were developed to be used in different countries and to assess different building types. This kind of "global" tool needs a prior adaptation of the sustainability benchmarks and priorities to the particular context of the country where the assessment is made, which is a very time-consuming process (Mateus and Bragança, 2011). It is also a process that hinders the practical application of this type of tool. On the other hand, there are tools developed for a specific country that are now being applied abroad without any prior adaptation. This aspect is causing distortions in the results of the sustainability assessment process and is producing wrong indications about the sustainable development of the construction industry, which in the end brings the concept of sustainable construction into disrepute (Mateus and Bragança, 2012).

The universe of tools for assessing the sustainability of the construction is already pretty numerous, each of which owes its character to different purposes and various institutes. In the healthcare buildings context, there are different building sustainability assessment methods, each one developed with a different structure and comprising different sustainability priorities, which entails the need to study and compare them.

The comparative analysis and categorising of tools is already published in some research papers such as Castro et al. (2015b), and Haapio and Viitaniemi (2008).

There are also different publications focusing on the need for developing sustainable buildings and which discuss the importance of using Building Sustainability Assessment (BSA) methods from the early design stage, such as Cole (1998), and Bragança et al. (2010). Other studies are oriented towards the development of building sustainability assessment schemes for specific regional contexts, such as Ali and Nsairat Al (2009). where the issue of building sustainability assessment in the context of developing countries, namely Jordan was discussed. There are also studies that were focused on the development of methods for a specific type of building, such as Mateus and Bragança (2011). They developed a BSA method, based on the international SBTool method, to be used in the assessment of residential buildings in the Portuguese context $\left(\right.$ SBTool $\left.^{\mathrm{PT}}-\mathrm{H}\right)$.

Others, such as the work of Berardi (2012), compared different building sustainability assessment methods to identify aspects of primary importance in the design of sustainable buildings and identified building energy performance as the most important criterion in sustainability rating systems. At a broader scale, there are other studies like for instance the one developed by Pires and Fidélis (2015) that discussed the implementation of sustainability indicators at the Portuguese local governance (municipalities) and concluded that it is still in early stages of development.

Regarding healthcare buildings, it is possible to enumerate some recognised methods in the market: BREEAM UK New Construction; LEED BD $+\mathrm{C}$ (Building Design and Construction); Green Star Design \& As Built; and CASBEE - NC (New Construction). Their characterization, analysis and comparison with the current standards in the field of sustainable construction (e.g. standards from the Technical Committee 350 of the European Committee for Standardisation), which has already been investigated by the authors (Castro et al., 2015b). Together these tools have driven market transformations around the world and from the analysis of results from their application to real cases, the following conclusions can be drawn (Castro et al., 2015b) (Guenther and Vittori, 2013): i) During the design phase, it is important to consider carefully every design decision, from the macro issues (e.g. selection of site and construction systems) to the micro issues (e.g. lighting and ventilation control); ii) Suitable decisions from the very beginning of the design stage produce better outcomes; iii) Good management during the construction phase is mandatory; iv) Continuous monitoring during the commissioning and operation phases, and covering all seasons, is fundamental; v) A sustainable building design will only result in a sustainable building if the operators and occupants are informed and educated about the sustainability aspects of the building; vi) Not every innovative system performs as anticipated and it is not the unique solution.

Therefore, this paper is aimed to present: i) a methodology to define the list of sustainability indicators and related system of weights to be used in an HBSA method; and ii) based on the developed method, a comprehensive framework for an HBSA method to be used in the Portuguese context.

Thus, this article is aimed at filling the gap identified in the state-of-art analysis by presenting:

- A methodology to develop a more objective list of sustainability indicators to be used in HBSA method, considering the work developed so far in the standardisation bodies (CEN and ISO) and the most relevant building sustainability assessment tools;

- A methodology to be used in the definition of the weighting system of an HBSA method, based on the perspective of the main sector's stakeholders; 
- A proposal for a comprehensive HBSA method adapted to the Portuguese environmental, sociocultural and economic contexts:

- An HBSA method that can be used in new, existing and renovated healthcare buildings.

The name of the method under development is Healthcare Building Sustainability Assessment Tool for Portugal (HBSAtool-PT). It is intended that this method should be practical, easily understandable and flexible enough to be simply adapted to diverse kinds of healthcare buildings and technologies. These are important features to promote sustainable design, construction, operation and maintenance of healthcare buildings.

\section{Portuguese context in the field of sustainability of healthcare buildings}

Since 2008, the Portuguese Ministry of Health has been published some important documents that should be considered in this kind of studies.

In 2008, it was released a document that sets the list of technical specifications and recommendations for national healthcare buildings. In 2012, it was re-published (ACSS, 2012) and contains several concerns about: architecture; outdoor spaces; electrical and mechanical systems; equipment and facilities for drainage and water supply; centralised technical management; management concepts for solid waste; and maintenance. In complement, there are also other regulations, which specify functional requirements of each healthcare space at different levels, such as: quality of indoor air; lighting; ventilation and temperature. Nonetheless, there is no law document or any recommendation in respect of the sustainable management of healthcare buildings.

The Guide "Guia de boas práticas para o setor da saúde" (in English: Guide to good practices in the healthcare sector) was published in 2013 by the Portuguese Ministry of Health (ACSS, 2013). This guide encourages: reduce water and energy consumptions and related costs; minimise the waste production; and new behaviours that support low carbon economies. It can be an instrument for diffusion of best sustainable practices to healthcare building users. The aim of this publication is to establish measures that require low investment and to promote the introduction of such measures in Portuguese hospital buildings (ACSS, 2013). Nowadays, in Portugal, on an annual basis, every hospital's administration must deliver the data to the Ministry of Health. Based on this data a set of "best" and "conventional" practices benchmarks for the Portuguese healthcare buildings was published (Castro et al., 2015a).

\section{Research stages}

\subsection{Definition}

The strategy adopted by this research is multi-dimensional that includes a diversity of qualitative and quantitative approaches and comprises mainly three consequential and cyclic steps: defining indicators; categorising indicators; and evaluating indicators. This steps, also defended by Ali and Nsairat Al (2009), are presented in Fig. 1.

Sustainability assessments are usually based on indicators, and an indicator is a signal or a sign that relays a multifaceted message, from hypothetically numerous sources, in an unassuming and useful manner (Kurtz et al., 2001). Therefore, the three most important objectives of the indicators are: simplification, quantification and communication (Geissler and Macoun, 2001). The definition of the list of sustainability indicators was based on the analysis of: i) the ongoing standardisation work of TC350 and ISO
TC59 ii) commonly accepted life-cycle assessment (LCA) methods; iii) the main indicators of most common building sustainability rating systems, developed in different countries (mainly the international SBTool method and most well-known HBSA methods); iv) some recognised examples of sustainable healthcare buildings; v) the key sustainability criteria defended by Sustainable Healthcare Architecture (Guenther and Vittori, 2013); vi) the Sustainableeffective design (SED) practices identified studying the renowned case studies (Castro et al., 2014); vii) and the Evidence-Based Design (EBD) issues examined in background literature (Baum et al., 2009).

The approach presented in this research is engrossed in the Portuguese context and therefore, it considers specific Portuguese's conditions and regulations, namely: i) the priorities set by the Portuguese Ministry of Health guide (ACSS, 2013); ii) the opinion of main stakeholders; iii) local regulations and targets, namely at environmental, energy performance and buildings functionality levels; and iv) the background of the Portuguese tool to assess the sustainability of residential buildings (BTool $\left.{ }^{\mathrm{PT}}-\mathrm{H}\right)$.

With this methodology, it was possible to define the first draft of the list of sustainability indicators that was after discussed with some Portuguese key sustainability actors, belonging to the Portuguese chapter of the International Initiative for a Sustainable Built Environment (iiSBE Portugal). From these discussions, it was possible to make some improvements in the list of indicators, by adding some indicators that were considered necessary and taking out others that were considered as no relevant for the Portuguese context.

After defining the sustainability indicators, they were structured in sustainability categories and areas. A category is a global indicator that summarises the performance of a building at the level of a key sustainability aspect. The sustainability areas summarise the performance of the building at the level of each main sustainable development goal. Each category embraces the indicators that influence the building sustainability at that level. After that, the categories were distributed among the different sustainability areas. At a first step, three areas were defined, to assess the building performance at the level of the three main dimensions of sustainability: environment, society, and economy. Since there are categories that match more than one main dimension, to improve the interpretation of results, two additional areas were created: Site and Technical. This approach is similar to the one used in the development of the SBTool method.

The following step is the development of the weighting system of the HBSA method. The reasoning behind the development of the weighting system is the fact that if the building sustainability is communicated using several grades, it is hard to understand the overall performance and therefore to compare different design approaches (Mateus and Bragança, 2011). To overcome this, the best method is to combine indicators within each category and sustainability area in order to obtain the respective performance levels (Allard et al., 2014). Consequently, the inclusion of a weighting system of indicators is a necessary stage in the process of developing assessment tools. This system can define the importance of each indicator according to the local context in which the tool is developed (Ali and Nsairat Al, 2009). The method used to define the weighting system is based on structured interviews with the main HBSA stakeholders (private and public): architects, engineers, sustainable construction experts; hospital managers; and members of the National Health Service.

\subsection{Collection of data}

Data collection related to the definition of indicators was based on the literature review and analysis of the following data: i) list of 
Developing the Healthcare Buildings Assessment indicators and structure

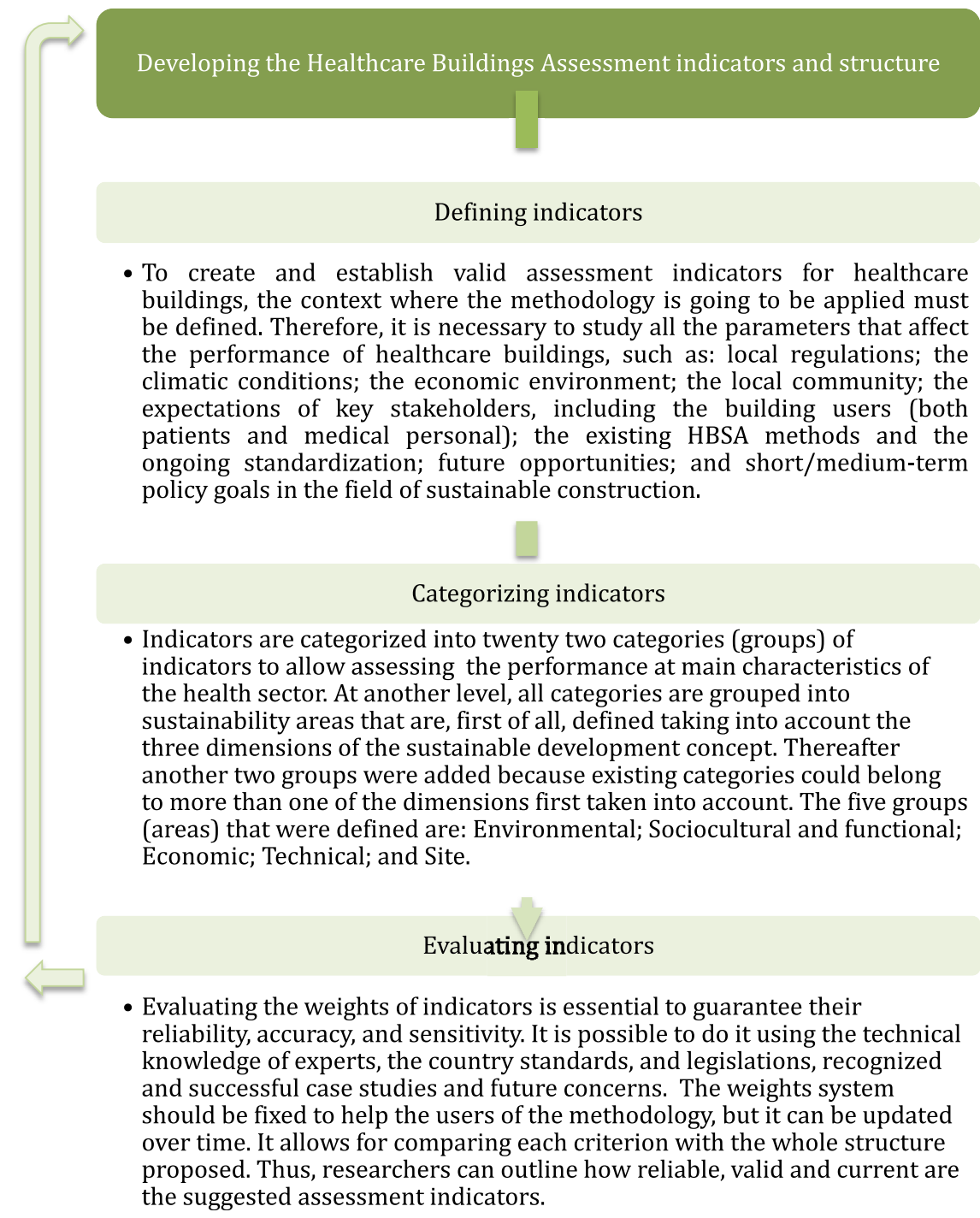

Fig. 1. Steps for developing, structuring and applying sustainability Indicators to develop the HBSA method (based on (Ali and Nsairat Al, 2009)).

indicators of different HBSA methods; ii) ongoing standardisation work that is being developed by CEN TC350 and ISO TC59; iii) and in recognised case studies.

Regarding the interviews, an online questionnaire was developed and sent to the main Portuguese stakeholders in the context of Portuguese healthcare buildings. The questionnaire allowed the opinion of each group of stakeholders at the level of each sustainability indicator to be understood. This method was used by several authors like Annunziata et al. (2016).

The questionnaire was organised in three parts. The first part is aimed at gathering the personal data related to the respondents (the work or expertise group they belong to; the area in the country where they work, etc.). The second one presents the proposed structure for the method and requests the respondent to rank the relative weight of each indicator, category and area. The third part is aimed at collecting comments and suggestions to improve the proposal structure. By using this approach, it was possible to collect the data necessary to develop the weighting system and to improve the structure of the tool.

Each respondent was asked to consider all tables presented in the questionnaire, where the indicators of each category and the categories of each area were presented. In each one, they needed to define the relative importance of each indicator or category in the quantification of building performance at different levels. Considering the grading scale presented in the questionnaire, each table should be assessed independently. Thus, the respondents rated comparatively from 1 to 5 all indicators and categories, and they could also assign equal ratings to two or more indicators. The most to the least important rating should be indicated, making sure that in each table would always show at least one indicator or category as being the most important. Table 1 presents an example of one

Table 1

Example of a table presented in the questionnaire (Category C3 - Soil use and biodiversity).

\begin{tabular}{l}
\hline C3 - Soil use and biodiversity \\
\hline Indicator \\
\hline I4 - Layout optimisation \\
I5 - Soil sealing \\
I6 - Reuse of previously built or contaminated areas \\
I7 - Ecological protection of the site \\
I8 - Rehabilitation of the surrounding \\
I9 - Use of native plants \\
I10 - Heat island effect
\end{tabular}


Table 2

Table presented in questionnaire to evaluate the relative weight of each area.

\begin{tabular}{ll}
\hline Area & Opinion \\
\hline Environmental & \\
Sociocultural and Functional & \\
Economy & \\
Technical & \\
Site & \\
Total & $100 \%$ \\
\hline
\end{tabular}

table presented in the questionnaire.

Finally, the definition of the relative importance that each area should have in quantifying the overall sustainability level of a building was requested. The sum of the percentage allocated to each area should be $100 \%$ (Table 2 ).

\subsection{Sampling process}

The sampling process was established to adequately support the development of sustainability indicators, a structure of the method and weighting system. This was based on the adaptive learning process, presented in Fig. 2.

Empirical research from around the world shows the benefits of engaging local communities in sustainability monitoring. Indicators developed within this type of approach are very helpful and usually contribute to improving the indicators developed by experts (Reed et al., 2006), because it helps the definition of priorities that answer to the particular local context. Nevertheless, as a primary step in the development of the method, it was decided to consider only the opinion of the main intervenient in the life cycle of the healthcare sector. The reasoning for this is to raise feasibility at this stage of the development of the HBSA method and to allow its application all over the country, independently from the local priorities. Future work will include questionnaires to local communities of different Portuguese territorial units to assess the necessity to introduce specific adaptations to the local context.

The sample is composed by a group of stakeholders, and they are from diverse fields: architects, engineers, sustainable construction experts; hospital managers; and members of the National Health Service. All participants were classified into three main groups:

1. Sustainable construction and building experts (qualified evaluators of Building Sustainability Assessment (BSA) methods, researchers, professionals and designers of building industry) and professionals with more than five years of construction and design experience in the healthcare context;

2. Hospital managers (including Local Managers of Energy and Carbon) and members of the National Health Service involved in strategic plans for energy reduction, etc.;

3. Professionals with less than five years of construction and design experience in the healthcare context or environmental and sustainable design (designers and building industry professionals).

The first group is composed of some sustainability experts and professionals identified by the Portuguese chapter of the International Initiative for a Sustainable Built Environment (iiSBE Portugal), the Portuguese Architects Association (OA) and the Portuguese Engineers Association (OE). The National Health Service (SNS) provided the sampling frame for the second group. The third group includes members of the listed organisations that were not included in Group I and II but those who have experience in designing healthcare buildings or in sustainable and environmental design. Although this last group has less experience than the other groups' members, it is assumed that it was important to consider their opinion in the weighting process since they are also actors in the process of designing sustainable buildings.

From a universe of 100 potential respondents, the total number of questionnaires received was 60 . The representativeness of each group was: $54 \%$ for the Group I, $18 \%$ for the Group II and 28\% for the Group III.

Saaty (1988) recommends that when there are different levels of

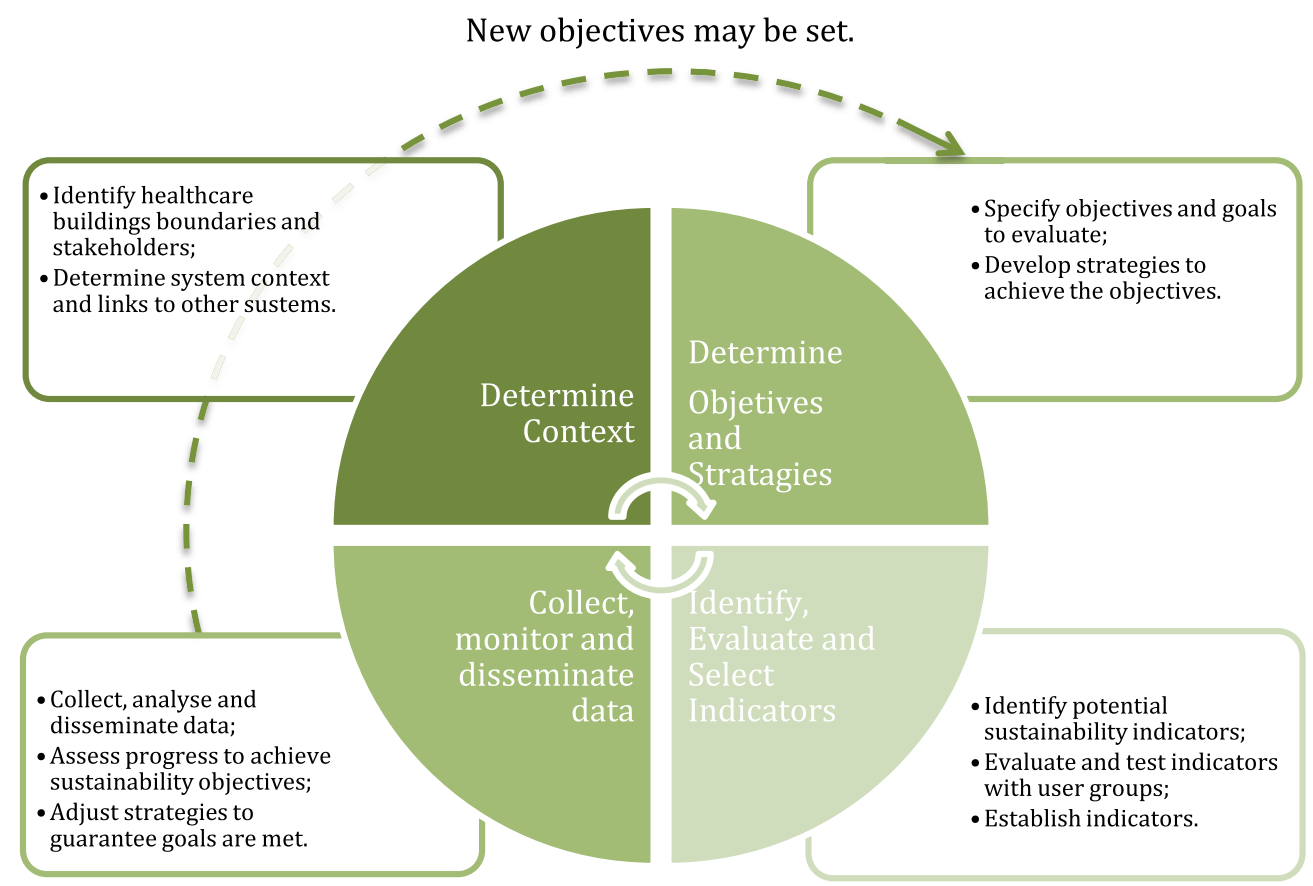

Fig. 2. Adaptive learning process for sustainability indicators development and application (based on (Reed et al., 2006)). 
expertise and experience in an interviewed sample, the sample should be organised into three different groups and the weight of the opinion of each group in the results should be different. Saaty (1988) proposes the following distribution of weights: the opinion of Group I in setting the average weighted mean was worth 45\%; Group II was worth 31\%; and Group III was worth $24 \%$. This means that higher weight was given to the opinion of those that have higher competencies in the field being analysed.

\subsection{Development of the weighting system for the assessment criteria}

The proposed criteria structure for HBSAtool-PT is based on a multi-dimensional approach that considers the most important environmental, societal and economic issues. The process for the developing system of weights for the assessment criteria should be both flexible and comprehensive. This procedure can be based on different methodologies: Experts panel; Endpoint method; Economy method; and Analytic Hierarchy Process (AHP) method. Based on the benefits and barriers of the different approaches, in this study, the AHP was used in the definition of the weighting system. Nevertheless, it is possible to say that the approach used is the result of a combination of the AHP and the Experts panel methodology since the qualitative relative weights were based on questionnaires to groups of experts.

AHP is a method of multi-criteria analysis, developed by Thomas L. Saaty in 1980. It is a mathematical technique to support decisionmaking that provides efficient means of dealing with multifaceted decision-making. It can also decrease complex and difficult decisions, taking into account a series of one-on-one comparisons by supporting with recognised and weighting assortment criteria, analysing the data collected ad furthering the process of decisionmaking (Ali and Nsairat Al, 2009). This method has been used by several authors to analyse data for similar purposes to the one of this study, as in (Sambasivan and Fei, 2008; Thanki et al., 2016).

AHP methodology is constructed on the following principles (Saaty, 2008): i) Decomposition - that structures the problem regarding its main components; ii) Comparative judgments - that are essential for paired comparison of items and investment options to get the weights of criteria and relative importance of investment options; iii) Synthesis of priorities -of criteria and options for weights into a global rating centred on which greatest option is decided upon.

\subsubsection{Definition of the weight of each category or indicator}

To develop the system of weights, both at the level of categories and indicators, the AHP method was used for the multi-criteria analysis. The AHP method can convert subjective human judgment into a quantitative analysis based on the principles of decomposition, comparative judgments and synthesis of priorities. Decomposition structures the problem according to its main components: focus, set of criteria for evaluation and the decision alternatives.

To enable this method to be applied, it is necessary to make paired comparisons, which are executed between categories and between indicators belonging to each of these. For this purpose, and considering the scale of importance on the questionnaire from 1 (the least) to 5 (the most important) - the respondents ranked the relative qualitative importance of each sustainability criterion.

Taking as an example the development of the weights of the indicators that belong to the Environmental category, the stages of the AHP method used were (an example of Environmental category):
1. To consider the number of answers given (level 5) by each Group (I, II and III) for each category;

2. To make paired comparison which starts with the selection of two items and measure the relative importance between them ( $\mathrm{C} 1$ vs $\mathrm{C} 2, \mathrm{C} 1$ vs $\mathrm{C} 3, \mathrm{C} 1$ vs $\mathrm{C} 4$, etc.). Then make a judgement of the performance of paired comparison of categories in achieving the goal.

3. To apply the AHP calculation process to synthesise paired comparisons (hierarchical synthesis). This is used to weight the Eigenvector entries by the weights of the items, and the sum is taken as overall weighted eigenvector entries. The method chosen to determine eigenvector was ANC method (Hsiao, 2002). In this method the figures of each column were divided by the sum of the columns, to add the element in each resulting row and divide this sum by the number of elements in the row (C1 vs total sum of the ratios of column C1; C2 vs total sum of the ratios of column $\mathrm{C} 1$; C3 vs total sum of the ratios of column $\mathrm{C} 1$ ).

4. To incorporate consistency of results through the analysis of the degree of consistency among the paired comparisons. This is made by calculating the following parameters: the Eigenvalue $\left(\lambda_{\max }\right)$; then the consistency index $(\mathrm{CI})$ and random index $(\mathrm{RI})$; and finally the consistency ratio (CR). If there is consistency in the analysis, it is possible to set the weights to be allocated to each of the categories under study.

Thus, to set the weight for each category and each indicator, a separate analysis was performed for each one of the five areas and each of the twenty-two categories respectively. Using the square matrix structure, it is possible to establish the relative importance (relative weight) of each indicator and category (Hambali et al., 2010). Finally, Equation (1) was used to determine the final weight of each category or indicator in the analysis, taking into consideration the opinion of different groups.

$$
\begin{aligned}
\text { Category/Indicator weight }= & W I_{I}(A W I)+W I_{I I}\left(A W_{I I}\right) \\
& +W I_{I I I}\left(A W_{I I I}\right)
\end{aligned}
$$

$W I=$ Weight Index assigned to each of the three groups (group $\mathrm{I}=0,45$; group $\mathrm{II}=0,31$; group $\mathrm{III}=0,24$ )

$A W=$ Average weight assigned by each group

\subsubsection{Averaging method used in the definition of the weight of each area}

The mechanism chosen to obtain the final weights for the five proposed areas is the sum of the average of the percentages derived from the responses of each group of experts. The weight of each area is the sum of the percentages assigned by each person, divided by the total number of responses from each group and multiplied by the Weighting Index (WI) assigned to each of the three groups. Equation (2) explains how the results were obtained.

Area weight $=W I_{I}\left(\frac{\sum P_{n I}}{n_{I}}\right)+W I_{I I}\left(\frac{\sum P_{n I I}}{n_{I I}}\right)+W I_{I I I}\left(\frac{\sum P_{n I I I}}{n_{I I I}}\right)$

$W I=$ Weight Index assigned to each of the three groups (group $\mathrm{I}=0,45$; group $\mathrm{II}=0,31$; and group $\mathrm{III}=0,24)$;

$P_{n}=$ percentage assigned by each respondent;

$n=$ number of answers. 


\section{Presentation and analysis of results}

\subsection{Structure proposed}

The proposed HBSAtool-PT is based on three levels of sustainability criteria (Table 3): indicators, categories and areas. Using the methodology presented above, a list of fifty-two sustainability indicators was defined. This list was organised in the following twenty-two categories: environmental life cycle impact assessment (related to environmental impacts embodied in the construction materials and the impacts resulting from the building operation); energy; soil use and biodiversity; materials and solid waste; water; user's health and comfort; controllability by the user; landscaping; passive design; mobility plan; space flexibility and adaptability; life cycle costs; local economy; environmental management systems; technical systems; security; durability; awareness and education for sustainability; skills in sustainability; local community; cultural value; and facilities. Each assessment category is identified by some indicators and belongs to one area of evaluation. The number and nature of indicators inside each category vary so that the most important sustainability issues in the Portuguese context are considered.

Regarding the definition of areas, the structure proposed for the HBSAtool-PT covers the three main dimensions of the sustainable development concept and includes the following five high-level sustainability areas (Table 3): environmental; sociocultural and functional; economy; technical; and site. The last two areas are not commonly considered as sustainability dimensions but are essential because there are categories that could belong to more than one of the three top dimensions (environmental, societal and economy).

Table 3

Structure proposed for the HBSA Portuguese method.

\begin{tabular}{|c|c|c|}
\hline Areas & Categories & Indicators \\
\hline A1 & C1 - Environmental life cycle impact assessment & I1 - Assessment the life impact of the building \\
\hline \multirow[t]{14}{*}{ Environmental } & C2 - Energy & $\begin{array}{l}\text { I2 - Primary energy consumption } \\
\text { I3 - Local energy production }\end{array}$ \\
\hline & C3 - Soil use and biodiversity & I4 - Layout optimisation \\
\hline & & I5 - Soil sealing \\
\hline & & I6 - Reuse of previously built or contaminated areas \\
\hline & & I7 - Ecological protection of the site \\
\hline & & I8 - Rehabilitation of the surrounding \\
\hline & & 19 - Use of native plants \\
\hline & & I10 - Heat island effect \\
\hline & C4 - Materials and Solid Waste & I11 - Construction waste \\
\hline & & I12 - Reused products and recycled materials \\
\hline & & I13 - Waste separation and storage \\
\hline & C5 - Water & I14 - Drinkable water consumption \\
\hline & & I15 - Recycling and recovery of effluents \\
\hline & & I16 - Treatment of contaminated effluents \\
\hline A2 & C6 - User's health and comfort & I17 - Natural ventilation \\
\hline \multirow[t]{15}{*}{ Sociocultural and functional } & & I18 - Toxicity of finishing materials \\
\hline & & I19 - Thermal comfort \\
\hline & & I20 - Visual comfort \\
\hline & & I21 - Acoustic comfort \\
\hline & & I22 - Indoor air quality \\
\hline & C7 - Controllability by the user & I23 - Ventilation and temperature \\
\hline & & I24 - Natural light \\
\hline & C8 - Landscaping & I25 - Visual link with the surrounding landscape \\
\hline & C9 - Passive design & I26 - Layout and Orientation \\
\hline & & I27 - Passive Systems \\
\hline & C10 - Mobility plan & I28 - Accessibilities \\
\hline & C11 - Space flexibility and adaptability & I29 - Availability and accessibility to social areas \\
\hline & & I30 - Space optimisation \\
\hline & & I31 - Space flexibility \\
\hline & & I32 - Space adaptability \\
\hline A3 & C12 - Life cycle costs & I33 - Initial cost \\
\hline \multirow{2}{*}{ Economy } & & I34 - Operational costs \\
\hline & C13 - Local economy & I35 - Hiring local goods and services \\
\hline A4 & c14 - Environmental management systems & I36 - Commissioning \\
\hline \multirow{11}{*}{ Technical } & & I37 - Environmental management plan \\
\hline & & I38 - Infection control \\
\hline & & I39 - Reducing noise pollution \\
\hline & C15 - Technical systems & I40 - Efficiency of lighting and air conditioning systems \\
\hline & C16 - Security & I41 - Occupants safety \\
\hline & C17 - Durability & I42 -Materials of high strength and durability \\
\hline & & I43 - Proper selection of furniture \\
\hline & C18 - Awareness and education for sustainability & I44 - Education of occupants \\
\hline & & I45 - Education of service providers \\
\hline & & I46 - Satisfaction surveys \\
\hline & C19 - Skills in sustainability & I47 - Integration in the team of a Qualified sustainability expert \\
\hline A5 & C20 - Local community & I48 - Local community development \\
\hline \multirow[t]{4}{*}{ Site } & C21 - Cultural value & I49 - Heritage framework \\
\hline & C22 -Facilities & I50 - Accessibility to public transport \\
\hline & & I51 - Low impact mobility \\
\hline & & I52 - Local amenities \\
\hline
\end{tabular}




\subsection{Weighting system for the sustainability criteria}

The second stage in the process is developing the weighting system for the sustainability indicators. This is aimed at ranking the significance of each indicator to be used, for instance, in the weighted average process that allows the calculation of the overall sustainability score.

Based on the results of the questionnaire, it was possible to obtain the final weight that each indicator, category and area should have in the overall sustainability performance. In this approach, the individual opinion of each respondent's group is also analysed and compared with the other two groups.

In the questionnaire, the respondents were firstly asked to input the qualitative relative weight that each indicator should have inside each category. Secondly, they have been invited to rank the importance of each category in the global assessment of each issue area. Finally, and given that the sum of the weight of each of the five areas must be $100 \%$, the relative importance of each one would have been requested.

\subsubsection{Definition of the weight of each area}

For simplicity and practical use, the weights of areas were rounded to the nearest integer number.

With the approach specified in Section 3.4.2, it was possible to assign the following weights for the sustainability areas (Fig. 3): 25\% for the Environmental; 20\% for the Sociocultural and Functional; $20 \%$ for the Economy; $20 \%$ for the Technical; and $15 \%$ for the Site area. Analysing Fig. 3 it is possible to conclude that the Environmental area has the highest score, next the three sustainability areas are considered to have similar importance, and only the "Site" area is deemed to have the lower weight. Fig. 4 presents the differences between the average weights assigned to each group of respondents.

From the analysis of Fig. 4, it is possible to conclude that Group I gave to the Environmental area the highest score, and this weight is clearly different from the weights assigned to the other areas. On the other hand, Group II highlights the Economy and Technical Areas. As in Group I, Group III gave the highest percentage of the Environmental area, but the differences between this and the Sociocultural and Functional area is, in this case, smaller. These differences are above all related to the profile of each Group's participants, taking into consideration their competences in the field of sustainability and the day-to-day problems they face. Regarding the last question of the survey, none of the respondents suggested a change at the level of the sustainability areas.

The Coefficients of Variance (CVs) of the obtained weights are also presented in Fig. 4, for the three groups of stakeholders and five areas of sustainability. CVs are a measure of reliability and lower values, under 0.40 , indicate that there is no considerable variability from one answer to another (Chandratilake and Dias,

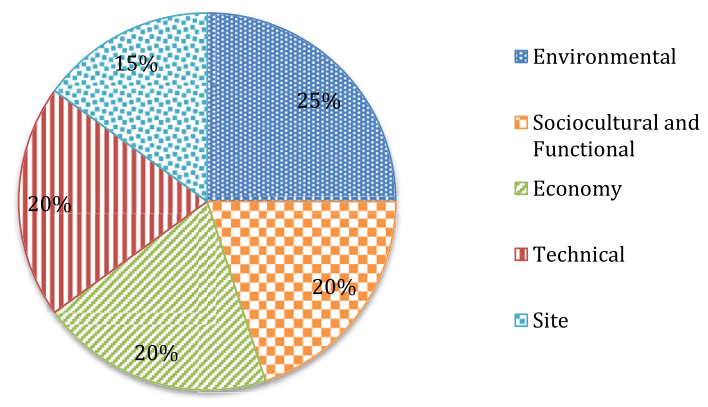

Fig. 3. Results obtained for the weight of each sustainability area.

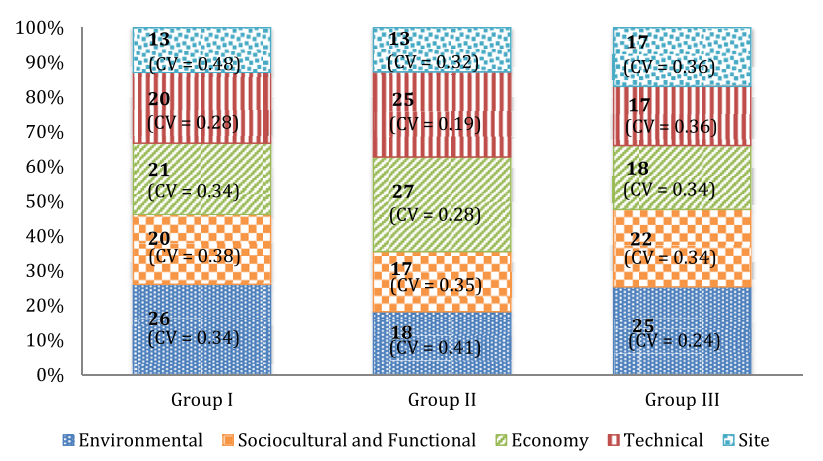

Fig. 4. Comparison between the average weights assigned by each group to the sustainability areas.

2015). From the analysis of Fig. 4, it is possible to conclude that there is no significant variability in the obtained answers, exception made to the following areas and groups, which CV is over 0.40: Site (Group I); and Environmental (Group III). Nevertheless, the effect of these two exceptions in the final weight of each area is very small since it is based on the weighted average opinion of each group.

\subsubsection{Definition of the weight of each category}

Fig. 5 presents the weight of each category inside the respective area. From the analysis of this Figure, it is possible to conclude that C2 (Energy) and C15 (Systems) are the most important categories in the Environmental area. C6 (Users' health and comfort) is the most important category in the Sociocultural and Functional area. In the Economy area, the category C12 (Life cycle costs) is considered the most relevant, comparable to C22 (Facilities) in the Site area. This is quite understandable, given the main concerns in the health sector: the users' comfort, the available facilities and own quality and costs control.

Regarding the open question at the bottom of the questionnaire, there were only two respondents suggesting changes in the framework of the method. By coincidence, they made the same suggestion that was to move category C9 (Passive design) to the Environmental area. Since the great majority of the respondents agreed with the proposed framework, it was decided to keep it as it was.

\subsubsection{Definition of the weight of each indicator}

Each category has an amount of indicators, and the way each indicator influences the performance at the level of each sustainability category is different.

Respondents argued that all the presented indicators are essential and representative of the category to which they belong. So, they agree that this list should be considered in the proposed assessment method. Additionally, there were no recommendations in the questionnaire's open question regarding this issue.

The respondents were asked to set the relative weight of each indicator in the assessment of the performance at the level of each category. Table 4, presents the weights assigned to each indicator, inside each sustainability area.

In the case of categories that only have one indicator, the weight of the category equals the weight of the indicator.

By analysing each category, it is possible to highlight the most important Indicator according to the opinion of the responders. In Category 2 (Environmental life cycle impact assessment), the weight of Indicators is balanced, whereas indicator I2 (Nonrenewable primary energy consumption) carries more weight. In Category 3 (Soil use and biodiversity), the most important is I4 (Layout optimisation), closely followed by I6 (Reuse of previously 


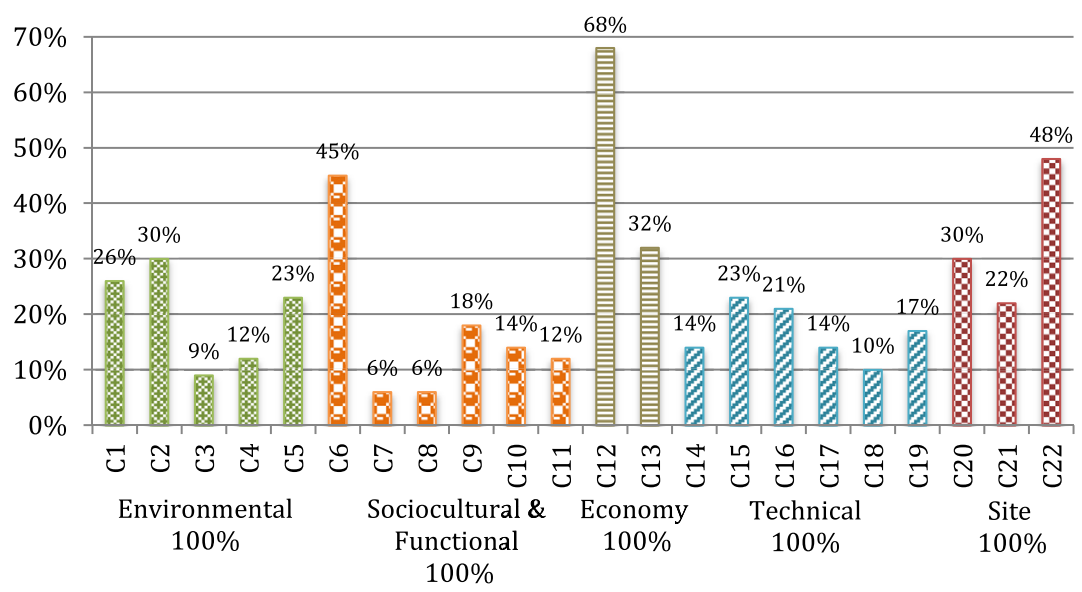

Fig. 5. Weighting of categories in each area.

built or contaminated areas). On the other hand, in Category 4 (Materials and Solid Waste), I13 (Waste separation and storage) achieved the highest score, and in Category 5 (Water), I14 (Drinkable water consumption) is the most important. Category 6 (User's health and comfort), shows that the most important is I22 (Indoor air quality), closely followed by I17 (Natural ventilation), and in Category 7 (Controllability by the user), the same weight was obtained for the two indicators. In Category 9 (Passive design), I27 (Passive Systems) is clearly greater than I26 (Layout and Orientation) and in Category 11 (Space flexibility and adaptability), the most important is I29 (Availability and accessibility to social areas), but the other three indicators have a balanced weight. Furthermore, in Category 12 (Life cycle costs), I34 (Operational costs) is clearly more important than I33 (Initial cost) and in Category 14 (Environmental management systems), the most important indicator is I38 (Infection control). In Category 17 (Durability), I42 (Materials of high strength and durability) is clearly more important than 143 (Proper selection of furniture) and in Category 18 (Awareness and education for sustainability), the most important indicator is 145 (Education of service providers), closely followed by I44 (Education of occupants). Finally, in Category 22 (Facilities), the most important indicator is I50 (Accessibility to public transport).

Overall the three groups highlighted the same indicators in each category. However, it should be noted that some significant differences were recorded between the views of each group. In Category 2 (Life cycle assessment of non-renewable primary energy consumption), group III gave more importance to I2 (Non-renewable primary energy consumption) than to I3 (Local energy production), while the other groups gave similar weights to the two Indicators. In Category 3 (Soil use and biodiversity), Group I considered I6 (Reuse of previously built or contaminated areas) greater than I4 (Layout optimisation). In Category 5 (Water), Group III considered I16 (Treatment of contaminated effluents) more important than I14 (Drinkable water consumption) and in Category 6 (User's health and comfort), Group II and III considered I22 (Indoor air quality) more important than I17 (Natural ventilation). Furthermore, in Category 7 (Controllability by the user), Group III considered I24 (Natural Light) greater than I23 (Ventilation and temperature) and in Category 11 (Space flexibility and adaptability), Group I found I29 (Availability and accessibility to social areas) the least important indicator. Finally, in Category 18 (Awareness and education for sustainability), Group II considered I44 (Education of occupants) the most important indicator, and Group III gave the same importance as 143 (Proper selection of furniture) from category C17.

\section{Discussion}

5.1. Comparison of weights between HBSAtool-PT and others HBSA existing methods

Sustainability assessment of healthcare buildings is still a new concept that is under development by several international organisations. Compared to other types, healthcare buildings are much more complex systems due to the specific and higher technical and functional requirements, and due to the number of different health service, they can cover. Additionally, based on the number of services they cover and population they serve, there are different types of healthcare buildings. This means that, for instance, some benchmarks can vary from type to type of healthcare building (e.g. the benchmarks for the energy consumption of a building that cover a small number of medical specialities cannot be the same as a national level healthcare building that covers all specialities) (Castro et al., 2015a).

Fig. 5 and Table 4 summarise the structure proposed for the HBSAtool-PT and the respective weights for each category and indicator. The weight of each area is already presented in Fig. 3. The sum of weights inside each category or area is $100 \%$. At this level, it is interesting to compare the proposed system of weights with other studies, to identify differences at the level of sustainability priorities.

As presented in Section 1, it is possible to identify some recognised existing methods in the market that are focused or can be used in the assessment of healthcare buildings: BREEAM UK New Construction; LEED BD $+\mathrm{C}$ (Building Design and Construction); Green Star - Design \& As Built; and CASBEE - NC (New Construction).

All of them have a similar structure and an equal weighting system. They have only one manual and tool to be applied to different types of new constructions, existing buildings and refurbishment, including healthcare buildings There are some criteria to be applied and at the level of each criterion, it specifies the type of building where it must be implemented (Castro et al., 2015b).

The tool versions on which this study is based are the latest at the time of submitting this study, namely: BREEAM UK New Construction, Non-Domestic Buildings (United-Kingdom) SD5076:5.0, 2014; LEED BD+C (Building Design and Construction) v4, updated April 2016; Green Star - Design \& As Built v1.1; and CASBEE for Building (New Construction) 2014 edition.

There are shared concerns among these four HBSA tools, such as: the use of energy; water efficiency; indoor and outdoor 
Table 4

Weight of each indicator in the quantification of building performance at the level of each category in HBSAtool-PT.

\begin{tabular}{|c|c|c|}
\hline ID & Designation & Weight (\%) \\
\hline A1 & Environmental & \\
\hline C1 & Environmental life cycle impact assessment & 100 \\
\hline I1 & Environmental the life impact of the building & 100 \\
\hline C2 & Energy & 100 \\
\hline 12 & Primary energy consumption & 53 \\
\hline I3 & Local energy production & 47 \\
\hline C3 & Soil use and biodiversity & 100 \\
\hline 14 & Layout optimisation & 24 \\
\hline 15 & Soil sealing & 15 \\
\hline I6 & Reuse of previously built or contaminated areas & 19 \\
\hline I7 & Site ecological protection & 16 \\
\hline 18 & Rehabilitation of the surrounding & 10 \\
\hline 19 & Use of native plants & 7 \\
\hline$I 10$ & Heat island effect & 8 \\
\hline C4 & Materials and Solid Waste & 100 \\
\hline I11 & Construction waste & 20 \\
\hline$I 12$ & Reused products and recycled materials & 36 \\
\hline$I 13$ & Waste separation and storage & 44 \\
\hline C5 & Water & 100 \\
\hline$I 14$ & Potable water consumption & 43 \\
\hline$I 15$ & Recycling and recovery of effluents & 23 \\
\hline$I 16$ & Treatment of contaminated effluents & 35 \\
\hline A2 & Sociocultural and functional & \\
\hline C6 & User's health and comfort & 100 \\
\hline$I 17$ & Natural ventilation & 23 \\
\hline$I 18$ & Toxicity of finishing materials & 17 \\
\hline$I 19$ & Thermal comfort & 18 \\
\hline$I 20$ & Visual comfort & 7 \\
\hline$I 21$ & Acoustic comfort & 10 \\
\hline$I 22$ & Indoor air quality & 25 \\
\hline C7 & Controllability by the user & 100 \\
\hline$I 23$ & Ventilation and temperature & 50 \\
\hline$I 24$ & Natural light & 50 \\
\hline C8 & Landscaping & 100 \\
\hline$I 25$ & Visual link with the surrounding landscape & 100 \\
\hline $\mathbf{C 9}$ & Passive design & 100 \\
\hline$I 26$ & Layout and Orientation & 38 \\
\hline$I 27$ & Passive Systems & 62 \\
\hline C10 & Mobility plan & 100 \\
\hline$I 28$ & Accessibilities & 100 \\
\hline C11 & Space flexibility and adaptability & 100 \\
\hline$I 29$ & Availability and accessibility to social areas & 31 \\
\hline$I 30$ & Space optimisation & 21 \\
\hline I31 & Space flexibility & 24 \\
\hline$I 32$ & Space adaptability & 25 \\
\hline A3 & Economy & \\
\hline C12 & Life cycle costs & 100 \\
\hline I33 & Initial cost & 31 \\
\hline I34 & Operational costs & 69 \\
\hline C13 & Local economy & 100 \\
\hline$I 35$ & Hiring local goods and services & 100 \\
\hline A4 & Technical & \\
\hline C14 & Environmental management systems & 100 \\
\hline I36 & Commissioning & 23 \\
\hline I37 & Environmental management plan & 24 \\
\hline$I 38$ & Infection control & 37 \\
\hline$I 39$ & Reducing noise pollution & 15 \\
\hline C15 & Technical systems & 100 \\
\hline 140 & Efficiency of lighting and air conditioning systems & 100 \\
\hline C16 & Security & 100 \\
\hline 141 & Occupant safety & 100 \\
\hline C17 & Durability & 100 \\
\hline 142 & Materials of high strength and durability & 71 \\
\hline 143 & Proper selection of furniture & 29 \\
\hline C18 & Awareness and education for sustainability & 100 \\
\hline 144 & Education of occupants & 39 \\
\hline 145 & Education of service providers & 41 \\
\hline 146 & Satisfaction surveys & 20 \\
\hline C19 & Skills in sustainability & 100 \\
\hline
\end{tabular}

Table 4 (continued)

\begin{tabular}{lll}
\hline ID & Designation & Weight (\%) \\
\hline I47 & Integration in the team of a qualified sustainability expert & 100 \\
\hline A5 & Site & \\
\hline C20 & Local community & $\mathbf{1 0 0}$ \\
I48 & Local community development & 100 \\
C21 & Cultural value & $\mathbf{1 0 0}$ \\
I49 & Patrimonial framework & 100 \\
C22 & Facilities & $\mathbf{1 0 0}$ \\
I50 & Accessibility to public transport & 58 \\
I51 & Low impact mobility & 24 \\
I53 & Local amenities & 18 \\
\hline
\end{tabular}

environmental quality; resources and material; service quality, and site strategies. Therefore, the proposed criteria for the HBSAtool-PT presented in this study uses a similar approach since those concerns are also considered. On the other hand, each method highlights different criteria according to where they were aimed to be applied. For instance, BREEAM UK New Construction and Green Star - Design \& As Built consider "Transport" and "Pollution" categories as individual evaluation categories, and LEED $\mathrm{BD}+\mathrm{C}$ and CASBEE - NC consider these issues as indicators that belong to other categories. Nevertheless, all the four methods consider "Energy" as the most important sustainability category.

Although there are differences between the list of indicators of the different tools, analysing ISO/AWI 21929 (ISO TS, 2010) it is possible to identify some core categories to enable comparison between the existing methods and the HBSAtool-PT (Fig. 6): Indoor environmental quality/Wellbeing; Energy; Water; Materials; Sustainable sites; Management; Transport; Pollution; Waste; Outdoor quality; Economic; and Cultural value.

Regarding this analysis, it is necessary to highlight that BREEAM UK New Construction, LEED BD+C, Green Star - Design \& As Built and the proposed method (HBSAtool-PT) uses a similar approach in the aggregation of the global sustainability score. Therefore, they can be compared. On the other hand, it is not possible to include CASBEE - NC in this analysis, because this tool uses a very specific method to quantify the global score. The specific method is based on the relation between two main groups of criteria: the "building environmental quality" (Q) and the "building environmental load" (LR) (CASBEE, 2010).

Fig. 6 presents, for the different methods in analysis, the weight that each ISO/AWI 21929 core category has in the global sustainability score.

Regarding Fig. 6 it is important to note that it is a method that gives much more importance to one core sustainability category than to others. In LEED the performance at the level of the energy related to sustainability indicators consists of weights of approximately $40 \%$ in the global sustainability score.

On the other hand, in BREEAM UK New Construction there is a more balanced weighting between all core criteria, and in Green Star - Design \& As Built it is possible to identify three main groups of core categories: Wellbeing, Energy and Materials. Compared with the other methods, the proposed HBSAtool-PT covers three additional core categories: Outdoor Quality; Economy; and Cultural Value. Moreover, in this method, Economy is one of the two leading sustainability categories, while this category is not considered in the other methods. Based on these differences, it is possible to conclude that this study is a great contribution to the development of the HBSA methods because it sets a more comprehensive list of sustainability priorities that is in line with the ongoing standardisation works. Additionally, in the Portuguese context, the importance given to the economy category is more accordingly to the weight that the healthcare sector plays in the Portuguese 
Table 5

Core sustainability indicators of the ISO/TS 21929-1: 2011 (ISO TS, 2011) covered by the analysed methods.

\begin{tabular}{|c|c|c|c|c|c|c|}
\hline \multicolumn{2}{|c|}{$\begin{array}{ll}\text { Core Indicators } & \text { Assessment methods } \\
\text { ISO 21929-1: 2011 }\end{array}$} & HBSAtool-PT & $\begin{array}{l}\text { LEED } \\
\mathrm{BD}+\mathrm{C}\end{array}$ & $\begin{array}{l}\text { BREEAM } \\
\text { UK New } \\
\text { Construction }\end{array}$ & CASBEE - NC & $\begin{array}{l}\text { Green Star- } \\
\text { Design \& } \\
\text { Built }\end{array}$ \\
\hline \multirow{4}{*}{$\begin{array}{l}\text { Access to } \\
\text { services }\end{array}$} & Public transportation & $\mathrm{X}$ & $\mathrm{X}$ & $\mathrm{X}$ & & $\mathrm{X}$ \\
\hline & $\begin{array}{l}\text { Personal modes of } \\
\text { transportation }\end{array}$ & $\mathrm{X}$ & $\mathrm{X}$ & $\mathrm{X}$ & & $\mathrm{X}$ \\
\hline & Green and open spaces & $\mathrm{X}$ & & & & \\
\hline & User relevant basic services & $\mathrm{X}$ & & & $\mathrm{X}$ & \\
\hline \multirow{3}{*}{$\begin{array}{l}\text { Aesthetic } \\
\text { quality }\end{array}$} & $\begin{array}{l}\text { Integration with the } \\
\text { surrounding }\end{array}$ & $\mathrm{X}$ & & & & \\
\hline & Impact of building in site & $\mathrm{X}$ & & & & \\
\hline & Local concerns & $\mathrm{X}$ & & & & \\
\hline Land & Site selection & $\mathrm{X}$ & $\mathrm{X}$ & $\mathrm{X}$ & & $\mathrm{X}$ \\
\hline \multirow{2}{*}{ Accessibility } & Building site & $\mathrm{X}$ & $\mathrm{X}$ & $\mathrm{X}$ & & $\mathrm{X}$ \\
\hline & Building & $\mathrm{X}$ & & & $\mathrm{X}$ & \\
\hline \multirow[b]{2}{*}{$\begin{array}{l}\text { Harmful } \\
\text { emissions }\end{array}$} & Potential impact on climate & $\mathrm{X}$ & $\mathrm{X}$ & $\mathrm{X}$ & $\mathrm{X}$ & $\mathrm{X}$ \\
\hline & $\begin{array}{l}\text { Potential impact on the } \\
\text { depletion of stratospheric } \\
\text { ozone layer }\end{array}$ & $\mathrm{X}$ & & $\mathrm{X}$ & & $\mathrm{X}$ \\
\hline $\begin{array}{l}\text { Non-renewable } \\
\text { resources }\end{array}$ & Use of resources & $\mathrm{X}$ & $\mathrm{X}$ & & & \\
\hline Fresh water & Use/Consumption & $\mathrm{X}$ & $\mathrm{X}$ & $\mathrm{X}$ & $\mathrm{X}$ & $\mathrm{X}$ \\
\hline Waste & Production & $\mathrm{X}$ & $\mathrm{X}$ & $\mathrm{X}$ & & $\mathrm{X}$ \\
\hline \multirow{2}{*}{$\begin{array}{l}\text { Indoor } \\
\text { environmental }\end{array}$} & Indoor conditions & $\mathrm{X}$ & $\mathrm{X}$ & $\mathrm{X}$ & $\mathrm{X}$ & $\mathrm{X}$ \\
\hline & Indoor air quality & $\mathrm{X}$ & $\mathrm{X}$ & $\mathrm{X}$ & $\mathrm{X}$ & $\mathrm{X}$ \\
\hline \multirow{3}{*}{ Safety } & Stability & $\mathrm{X}$ & $\mathrm{X}$ & $\mathrm{X}$ & & \\
\hline & Resistance & & $\mathrm{X}$ & $\mathrm{X}$ & & \\
\hline & Fire safety & & & & & \\
\hline Serviceability & Planning/Measurement & $\mathrm{X}$ & & $\mathrm{X}$ & & $\mathrm{X}$ \\
\hline \multirow{2}{*}{ Adaptability } & $\begin{array}{l}\text { Adaptability for changed use } \\
\text { purpose }\end{array}$ & $\mathrm{X}$ & $\mathrm{X}$ & & $\mathrm{X}$ & \\
\hline & $\begin{array}{l}\text { Adaptability for climate } \\
\text { change }\end{array}$ & & & & & \\
\hline Costs & Planning/Measurement & $\mathrm{X}$ & & $\mathrm{X}$ & & $\mathrm{X}$ \\
\hline Maintainability & Planning/Assessment & $\mathrm{X}$ & & $\mathrm{X}$ & & $\mathrm{X}$ \\
\hline
\end{tabular}

economy, and it reflects the stakeholders' opinions gathered in the survey.

Besides the comparison with the most well know HBSA methods that already exist in the market, it is also worthy to compare the results with other studies developed for specific countries. As an example, results are also compared with the following to studies: Duurzaamheidsmeter Zorg method (Stevanovic et al., 2016); and the Sri Lanka weighting system (Chandratilake and Dias, 2013). Duurzaamheidsmeter Zorg is an adaptation of BREEAM UK New Construction method adjusted for the healthcare facilities and taking in consideration the Belgian context (Stevanovic et al., 2016). The Sri Lanka survey is not focused in healthcare buildings in particular, but the building sector in general. Nevertheless, since the HBSATool-PT and the Sri Lanka weighting systems used a similar approach to rank the priority of sustainability indicators, applied to different contexts, it is interesting to compare the results of the two studies.

Fig. 7 compares the proposed HBSAtool-PT system of weights with the weights of the two mentioned studies, considering the ISO/AWI 21929 core sustainability categories (ISO TS, 2010).

From the analysis of Fig. 6, it is possible to conclude that, compared with the other two studies, HBSAtool-PT uses a more comprehensive approach, since it covers all ISO/AWI 21929 core categories. While the other two studies are above focused in the environment dimension of sustainability, HBSAtool-PT also considers the core sustainability categories related to the other two sustainability dimensions: economy and society.

\subsection{Comparison of criteria between ongoing standardisation and HBSA methods}

According to the ongoing standardisation, Tables 5 and 6 list the sustainable aspects, including environmental, societal and economic, that according to ISO/TC 59/SC 17 (ISO TS, 2011) and CEN/TC 350 (CEN TC 350 2011, 2012a, b) (CEN TC 350, 2011), (CEN TC 350, 2012a) (CEN TC 350, 2012b), mandates should be considered when assessing the sustainability of construction works. These tables present how the four HBSA existing methods and the proposed HBSAtool-PT method cover the list of the standardised sustainability criteria. These Tables improve and complete others results previously published by Castro et al. (2015b).

Analysing Tables 5 and 6 and regarding societal criteria, it is possible to conclude that all tools are almost consistent with the EN 15643-3: 2010 and ISO 21929: 2011 since they cover most of the listed criteria. Furthermore, from the analysis of the abovementioned Tables, it is also possible to conclude that Green Star - Design \& As Built is the method that covers less standardised sustainability criteria and HBSAtool-PT and LEED BD+C are those that are more consistent with ongoing standardisation. Regarding "Safety" category it is necessary to note that "Resistance" and "Fire safety" are already regulated in Portugal with other specific legal regulations, so these indicators were not taken into account in HBSAtool-PT. Regarding Environmental criteria, HBAStool-PT is the one that covers more standardised indicators followed by LEED $\mathrm{BD}+\mathrm{C}$. Results also show that the most relevant differences are 
Table 6

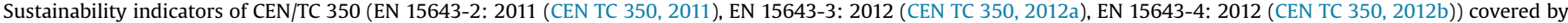
analysed methods.

\begin{tabular}{|c|c|c|c|c|c|c|}
\hline \multicolumn{2}{|c|}{$\begin{array}{l}\text { Core Indicators } \\
\text { CEN EN 15643-2: 2011; } \\
\text { EN 15643-3: 2012; EN 15643-4: } 2012\end{array}$} & HBSAtool-PT & $\begin{array}{l}\text { LEED } \\
\mathrm{BD}+\mathrm{C}\end{array}$ & $\begin{array}{l}\text { BREEAM } \\
\text { UK New } \\
\text { Construction }\end{array}$ & CASBEE - NC & $\begin{array}{l}\text { Green Star - } \\
\text { Design \& } \\
\text { Built }\end{array}$ \\
\hline \multicolumn{7}{|c|}{ Environmental performance } \\
\hline \multirow{6}{*}{$\begin{array}{l}\text { Environmental } \\
\text { impacts }\end{array}$} & Global warming potential & $\mathrm{X}$ & & $\mathrm{X}$ & & \\
\hline & $\begin{array}{l}\text { Depletion potential of the } \\
\text { stratospheric ozone layer }\end{array}$ & $\mathrm{X}$ & & $\mathrm{X}$ & & $\mathrm{X}$ \\
\hline & $\begin{array}{l}\text { Acidification potential of soil } \\
\text { and water sources }\end{array}$ & $\mathrm{X}$ & & & & \\
\hline & Eutrophication potential & & & & & \\
\hline & $\begin{array}{l}\text { Formation potential of } \\
\text { tropospheric ozone }\end{array}$ & & & & & \\
\hline & Abiotic depletion potential & & & & & \\
\hline \multirow{2}{*}{ Resource input } & $\begin{array}{l}\text { Use of renewable primary } \\
\text { energy }\end{array}$ & $\mathrm{X}$ & $\mathrm{X}$ & & & \\
\hline & $\begin{array}{l}\text { Use of non-renewable primary } \\
\text { energy }\end{array}$ & $\mathrm{X}$ & $\mathrm{X}$ & $\mathrm{X}$ & $\mathrm{X}$ & $\mathrm{X}$ \\
\hline \multirow{4}{*}{ Resource use } & Use of secondary material & $\mathrm{X}$ & $\mathrm{X}$ & $\mathrm{X}$ & & $\mathrm{X}$ \\
\hline & $\begin{array}{l}\text { Use of renewable secondary } \\
\text { fuels }\end{array}$ & & & & & \\
\hline & $\begin{array}{l}\text { Use of non-renewable } \\
\text { secondary fuels }\end{array}$ & & & & & \\
\hline & Use of net fresh water & $\mathrm{X}$ & $\mathrm{X}$ & $\mathrm{X}$ & $\mathrm{X}$ & $\mathrm{X}$ \\
\hline \multirow{4}{*}{ Waste } & Hazardous waste disposed & $\mathrm{X}$ & $\mathrm{X}$ & & & \\
\hline & $\begin{array}{l}\text { Non-hazardous waste } \\
\text { disposed }\end{array}$ & $\mathrm{X}$ & $\mathrm{X}$ & & & \\
\hline & Radioactive waste disposed & & & & & \\
\hline & Use of net fresh water & $\mathrm{X}$ & & & & \\
\hline \multirow{4}{*}{ Output flows } & Components for re-use & $\mathrm{X}$ & & & & $\mathrm{X}$ \\
\hline & Materials for recycling & $\mathrm{X}$ & $\mathrm{X}$ & & $\mathrm{X}$ & $\mathrm{X}$ \\
\hline & Materials for energy recovery & & & & & \\
\hline & Exported energy & & & & & \\
\hline \multicolumn{7}{|c|}{ Societal performance } \\
\hline \multirow{2}{*}{ Accessibility } & For people with specific needs & $\mathrm{X}$ & & & & \\
\hline & To building services & $\mathrm{X}$ & $\mathrm{X}$ & & $\mathrm{X}$ & \\
\hline \multirow{4}{*}{ Adaptability } & $\begin{array}{l}\text { To accommodate individual } \\
\text { user requirements }\end{array}$ & $\mathrm{X}$ & $\mathrm{X}$ & & $\mathrm{X}$ & \\
\hline & $\begin{array}{l}\text { To accommodate the change } \\
\text { of user requirements }\end{array}$ & $\mathrm{X}$ & $\mathrm{X}$ & & $\mathrm{X}$ & \\
\hline & $\begin{array}{l}\text { To accommodate technical } \\
\text { changes }\end{array}$ & $\mathrm{X}$ & & & & \\
\hline & $\begin{array}{l}\text { To accommodate the change } \\
\text { of use }\end{array}$ & $\mathrm{X}$ & $\mathrm{X}$ & & & \\
\hline \multirow{5}{*}{$\begin{array}{l}\text { Health and } \\
\text { comfort }\end{array}$} & Acoustic characteristics & $\mathrm{X}$ & $\mathrm{X}$ & $\mathrm{X}$ & $\mathrm{X}$ & $\mathrm{X}$ \\
\hline & $\begin{array}{l}\text { Characteristics of indoor air } \\
\text { quality }\end{array}$ & $\mathrm{X}$ & $\mathrm{X}$ & $\mathrm{X}$ & $\mathrm{X}$ & $\mathrm{X}$ \\
\hline & $\begin{array}{l}\text { Characteristics of visual } \\
\text { comfort }\end{array}$ & $\mathrm{X}$ & $\mathrm{X}$ & $\mathrm{X}$ & $\mathrm{X}$ & $\mathrm{X}$ \\
\hline & $\begin{array}{l}\text { Characteristics of water } \\
\text { quality }\end{array}$ & $\mathrm{X}$ & $\mathrm{X}$ & $\mathrm{X}$ & & \\
\hline & $\begin{array}{l}\text { Electromagnetic } \\
\text { characteristics }\end{array}$ & & & & & \\
\hline
\end{tabular}




\begin{tabular}{|c|c|c|c|c|c|c|}
\hline & Spatial characteristics & $\mathrm{X}$ & $\mathrm{X}$ & $\mathrm{X}$ & $\mathrm{X}$ & $\mathrm{X}$ \\
\hline & Thermal characteristics & $\mathrm{X}$ & $\mathrm{X}$ & $\mathrm{X}$ & $\mathrm{X}$ & $\mathrm{X}$ \\
\hline \multirow{5}{*}{$\begin{array}{l}\text { Loadings on the } \\
\text { neighbourhood }\end{array}$} & Noise & $\mathrm{X}$ & $\mathrm{X}$ & $\mathrm{X}$ & $\mathrm{X}$ & \\
\hline & $\begin{array}{l}\text { Emissions to outdoor air, soil } \\
\text { and water }\end{array}$ & $\mathrm{X}$ & $\mathrm{X}$ & $\mathrm{X}$ & $\mathrm{X}$ & $\mathrm{X}$ \\
\hline & Glare and overshadowing & & & $\mathrm{X}$ & $\mathrm{X}$ & $\mathrm{X}$ \\
\hline & Shocks and vibrations & & & & $\mathrm{X}$ & \\
\hline & Localized wind effects & & $\mathrm{X}$ & & $\mathrm{X}$ & $\mathrm{X}$ \\
\hline Maintenance & Operations & $\mathrm{X}$ & $\mathrm{X}$ & $\mathrm{X}$ & $\mathrm{X}$ & $\mathrm{X}$ \\
\hline \multirow{4}{*}{ Safety/security } & Resistance to climate change & & $\mathrm{X}$ & & & \\
\hline & $\begin{array}{l}\text { Resistance to accidental } \\
\text { actions }\end{array}$ & & & & $\mathrm{X}$ & \\
\hline & Personal safety and security & $\mathrm{X}$ & $\mathrm{X}$ & $\mathrm{X}$ & & \\
\hline & $\begin{array}{l}\text { Security against interruptions } \\
\text { of utility supply }\end{array}$ & $\mathrm{X}$ & $\mathrm{X}$ & $\mathrm{X}$ & & \\
\hline $\begin{array}{l}\text { Sourcing of } \\
\text { materials and } \\
\text { services }\end{array}$ & $\begin{array}{l}\text { Responsible sourcing and } \\
\text { traceability of products and } \\
\text { services }\end{array}$ & & $\mathrm{X}$ & $\mathrm{X}$ & & $\mathrm{X}$ \\
\hline $\begin{array}{l}\text { Stakeholder } \\
\text { involvement }\end{array}$ & $\begin{array}{l}\text { The opportunity for interested } \\
\text { parties to engage in the } \\
\text { decision-making process for } \\
\text { the realisation of a building }\end{array}$ & $\mathrm{X}$ & & $\mathrm{X}$ & & \\
\hline \multicolumn{7}{|c|}{ Economic performance } \\
\hline \multirow{10}{*}{$\begin{array}{l}\text { Economic } \\
\text { impacts and } \\
\text { aspects at the } \\
\text { before Use } \\
\text { Stage }\end{array}$} & $\begin{array}{l}\text { Costs directly related to the } \\
\text { purchase or rental of the site }\end{array}$ & & & & & \\
\hline & $\begin{array}{l}\text { Cost of products supplied at } \\
\text { factory gate ready for } \\
\text { construction }\end{array}$ & $\mathrm{X}$ & & $\mathrm{X}$ & & $\mathrm{X}$ \\
\hline & $\begin{array}{l}\text { Costs incurred between } \\
\text { factory and site }\end{array}$ & & & & & \\
\hline & Professional fees & $\mathrm{X}$ & & & & \\
\hline & $\begin{array}{l}\text { Temporary and enabling } \\
\text { works }\end{array}$ & & & $\mathrm{X}$ & & $\mathrm{X}$ \\
\hline & Construction of asset & & & $\mathrm{X}$ & & $\mathrm{X}$ \\
\hline & $\begin{array}{l}\text { Initial adaptation or fit out of } \\
\text { asset }\end{array}$ & & & & & \\
\hline & $\begin{array}{l}\text { Landscaping, external works } \\
\text { on the curtilage }\end{array}$ & & & & & \\
\hline & $\begin{array}{l}\text { Taxes and other costs related } \\
\text { to permission to build }\end{array}$ & & & & & \\
\hline & Subsidies and incentives & & & & & \\
\hline \multirow{10}{*}{$\begin{array}{l}\text { Economic } \\
\text { impacts and } \\
\text { aspects } \\
\text { excluding the } \\
\text { building in } \\
\text { operation at the } \\
\text { Use Stage }\end{array}$} & $\begin{array}{l}\text { Building related insurance } \\
\text { costs }\end{array}$ & & & & & \\
\hline & $\begin{array}{l}\text { Leases and rentals payable to } \\
\text { third parties }\end{array}$ & & & & & \\
\hline & Cyclical regulatory costs & & & & & \\
\hline & Taxes & & & & & \\
\hline & Subsidies and incentives & & & & & \\
\hline & $\begin{array}{l}\text { Revenue from sale of asset or } \\
\text { elements, but not part of a } \\
\text { final disposal }\end{array}$ & & & & & \\
\hline & $\begin{array}{l}\text { Third party income during } \\
\text { operation }\end{array}$ & & & & & \\
\hline & $\begin{array}{l}\text { Repairs and replacement of } \\
\text { minor components/small areas }\end{array}$ & $\mathrm{X}$ & & & & \\
\hline & $\begin{array}{l}\text { Replacement or refurbishment } \\
\text { of major systems and } \\
\text { components }\end{array}$ & $\mathrm{X}$ & & & & \\
\hline & Adaptation or subsequent fit & & & & & \\
\hline
\end{tabular}


Table 6 (continued)

\begin{tabular}{|c|c|c|c|c|c|c|}
\hline & $\begin{array}{l}\text { out of asset - fitting out or } \\
\text { modification of existing } \\
\text { buildings }\end{array}$ & & & & & \\
\hline & Cleaning & $\mathrm{X}$ & & $\mathrm{X}$ & & $\mathrm{X}$ \\
\hline & Grounds maintenance & $\mathrm{X}$ & & & & \\
\hline & Redecoration & & & & & \\
\hline & $\begin{array}{l}\text { Disposal Inspections at end of } \\
\text { lease period }\end{array}$ & & & & & \\
\hline & End of lease & & & & & \\
\hline & $\begin{array}{l}\text { Planned adaptation or planned } \\
\text { refurbishment of asset in use }\end{array}$ & & & & & \\
\hline & $\begin{array}{l}\text { Building related facility } \\
\text { management costs }\end{array}$ & $\mathrm{X}$ & & $\mathrm{X}$ & & $\mathrm{X}$ \\
\hline Economic & Operational energy costs & $\mathrm{X}$ & $\mathrm{X}$ & $\mathrm{X}$ & $\mathrm{X}$ & $\mathrm{X}$ \\
\hline impacts and & Operational water costs & $\mathrm{X}$ & $\mathrm{X}$ & $\mathrm{X}$ & $\mathrm{X}$ & $\mathrm{X}$ \\
\hline aspects of the & Taxes & & & & & \\
\hline $\begin{array}{l}\text { building } \\
\text { Operational } \\
\text { Use }\end{array}$ & Subsidies and incentives & & & & & \\
\hline & $\begin{array}{l}\text { Deconstruction/ dismantling, } \\
\text { demolition }\end{array}$ & & & & & $\mathrm{X}$ \\
\hline $\begin{array}{l}\text { Economic } \\
\text { impacts and }\end{array}$ & $\begin{array}{l}\text { All transport costs associated } \\
\text { with the process of } \\
\text { deconstruction and disposal of } \\
\text { the built asset }\end{array}$ & & & & & \\
\hline aspects at the & Fees \& taxes & & & & & \\
\hline & $\begin{array}{l}\text { Costs and/or revenues from } \\
\text { reuse, recycling, and energy } \\
\text { recovery at end of life }\end{array}$ & & & & & \\
\hline & Revenue from sale land & & & & & \\
\hline
\end{tabular}

found at the level of the economic dimension since most standardised economic criteria are not directly addressed. Rather than assessing the standardised economic criteria directly, the developed framework considers that these are implicitly contained in some environmental principles, such as the: reduction of resource consumption, energy management and water efficiency.

\section{Conclusions}

The structure of HBSAtool-PT can help to produce significant benefits not evident in standard design and building management practices. Additionally, and compared with other existing approaches, it allows the integration of more widespread social and economic concerns, rather than be focusing on reducing environmental impacts.

If decisions are made at the early design stage, both in new construction or rehabilitation operations, it is possible to integrate sustainability principles, with a greater probability of success and reduced cost. This is only possible using comprehensive and systematic approaches that can be used in decision-making by the

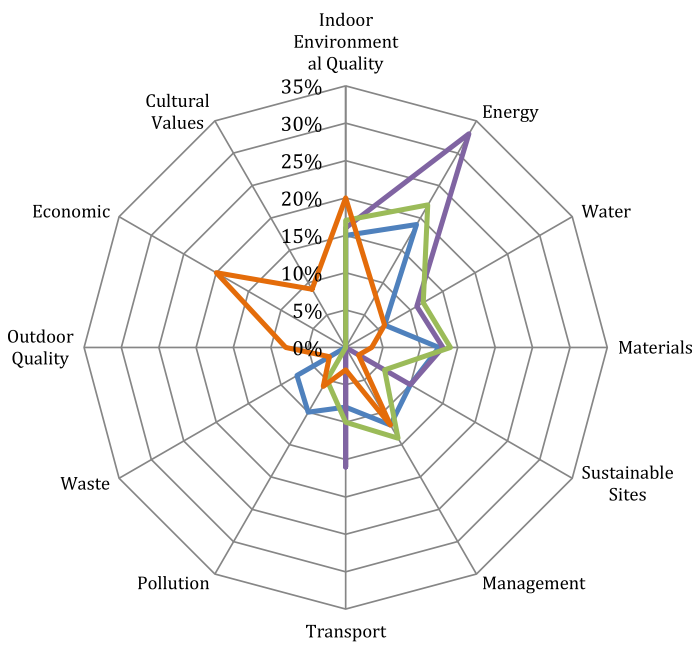

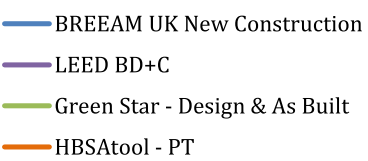

Fig. 6. Comparison between the weights systems of each analysed method, considering the ISO/AWI 21929 core categories. 


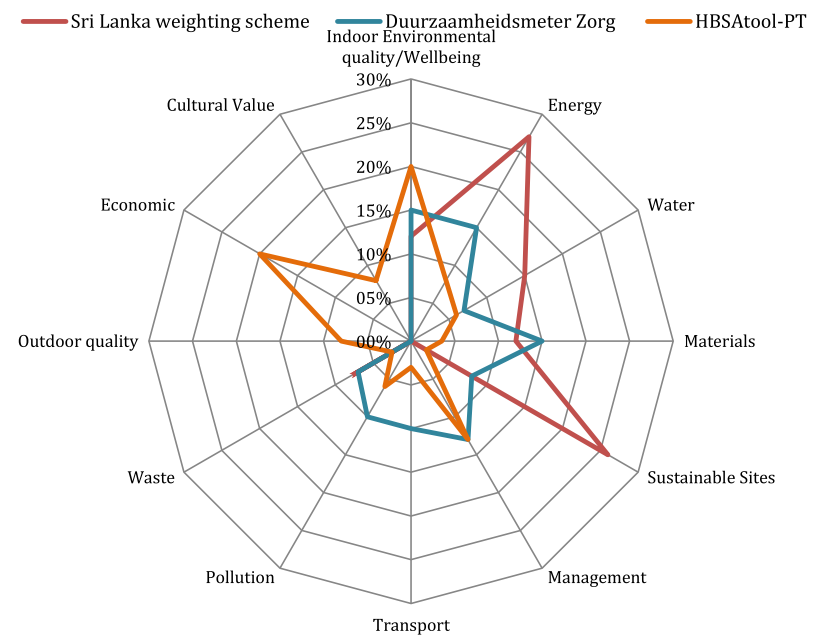

Fig. 7. Comparison between the system of weights of HBSAtool-PT, Duurzaamheidsmeter Zorg, and Sri Lanka weighting system, considering the ISO/AWI 21929 core categories.

design teams. It is also necessary to highlight that, to be effective, the approach used must be aligned with the environmental, societal and economic contexts of the country/region where it is going to be applied.

In this sense, the HBSAtool-PT presents a structured list of sustainability indicators with respective weights in the overall sustainability and is aimed at promoting the development of more sustainable healthcare buildings in Portugal.

Additionally, since there is no common international understanding regarding the weight of each indicator has in the global sustainability assessment, this research is also aimed at presenting a methodology to develop the system of weights of a HBSA methods.

Regarding the methodology used, since there is no common international understanding regarding the weight of each indicator, it is based on the results of a questionnaire that involved the main Portuguese healthcare sector stakeholders. This approach is very important since it allows for: i) considering the knowledge and experience of different stakeholders in the process of designing, using and maintaining a healthcare building; ii) validating the list of sustainability indicators and the proposed framework for the method; iii) understanding the relative importance of each sustainability area, category and indicator in global sustainability; and v) considering the specific environmental, economic and societal contexts.

Finally, this paper presents an approach to assessing the sustainability of healthcare buildings that is aimed at evolving existing approaches. The proposed structure is based on the limitations of the recognised existing methods and on ongoing standardisation.

This kind of studies and initiatives may be of significant advantage in seeking improvement to the performance of healthcare buildings. From this study, some conclusions that can be relevant to the debate regarding the efficiency of investment in healthcare buildings are:

- First, these assessment methods can be used: to raise awareness and to promote sustainable practices in healthcare buildings; to reduce consumptions and costs and consequently the environmental and economic impacts of these buildings; and to support decision-making of both design teams and building managers in the process of designing and operating sustainable healthcare buildings;
- Secondly, by considering the main stakeholders' opinion, both the list of indicators and system of weights are more aligned with their expectations, therefore increasing their potential effectiveness.

- Thirdly, by proving a list of sustainability indicators and the corresponding assessment method and benchmarks, it allows hospital managers to compare the operating efficiency of their building with conventional and best practices on the national scene.

\section{Acknowledgments}

The authors acknowledge the Portuguese Foundation for Science and Technology and POPH/FSE for its financial support for this study (Reference SFRH/BD/77959/2011). Special thank is also addressed to Donald Ellis for proofreading the English text.

\section{References}

ACSS, 2013. Guide to good practices in the healthcare sector (Guia de boas práticas para o sector da saúde). ACSS, Lisbon.

ACSS, 2012. Recommendations and Technical Specifications of the Hospital Building. In: Recomendações e especificações técnicas do Edifício Hospitalar. ACSS Administração Central do Sistema de Saúde, Lisboa.

Ali, H.H., Nsairat Al, S.F., 2009. Developing a green building assessment tool for developing countries - case of Jordan. Build. Environ. 44, 1053-1064. http:// dx.doi.org/10.1016/j.buildenv.2008.07.015.

Allard, F., Cherqui, F., Wurtz, E., Mora, L., 2014. A Methodology to Assess the Sustainability of Rehabilitation Projects in Urban Buildings. University of La Rochelle, 1-9.

Annunziata, E., Testa, F., Iraldo, F., Frey, M., 2016. Environmental responsibility in building design: an Italian regional study. J. Clean. Prod. 112, 639-648. http:// dx.doi.org/10.1016/j.jclepro.2015.07.137.

ASHE, 2002. Green healthcare Construction Guidance Statement. ASHE, Chicago.

Baum, M., Shepley, M., Rostenberg, B., Ginberg, R., 2009. Eco-effective Design and Evidence-based Design: Removing Barriers to Integration. AIA Board Knowledge Committee, San Francisco.

Berardi, U., 2012. Sustainability assessment in the construction sector: rating systems and rated buildings. Sustain. Dev. 20, 411-424. http://dx.doi.org/10.1002/ sd.532/full.

Bragança, L., Mateus, R., Koukkari, H., 2010. Build. Sustain. Assess. 2, 2010-2023. http://dx.doi.org/10.3390/su2072010.

Brody, C., 2001. Setting Healthcare's environmental agenda. In: Harms, H.C.W. (Ed.), Presented at the Setting Healthcare's Environmental Agenda, pp. 1-65.

CASBEE, 2010. CASBEE for New Construction. JSBC.

Cassidy, R., 2003. White paper on Sustainability. In: Building Design and Construction Magazine. Oak Brook, 1-48.

Castro, M., Mateus, R., Serôdio, F., Bragança, L., 2015a. Development of benchmarks for operating costs and resources consumption to be used in healthcare building sustainability assessment methods. Sustainability 7, 13222-13248. http://dx.doi.org/10.3390/su71013222.

Castro, M.F., Mateus, R., Bragança, L., 2015b. A critical analysis of building sustainability assessment methods for healthcare buildings. Environ. Dev. Sustain. 17, 1381-1412. http://dx.doi.org/10.1007/s10668-014-9611-0.

Castro, M.F., Mateus, R., Braganç, L., 2014. Proposal for a healthcare building sustainability assessment (HBSA) method. In: World SB14 Barcelona, Barcelona, pp. 607-613.

CEN TC 350, 2012a. EN 15643-3 Sustainability of Construction Works - Assessment of Buildings - Part 4: Framework for the Assessment of Social Performance. CEN, Brussels.

CEN TC 350, 2012b. EN 15643-4 Sustainability of Construction Works - Assessment of Buildings - Part 4: Framework for the Assessment of Economic Performance. CEN, Brussels.

CEN TC 350, 2011. EN 15643-2 Sustainability of Construction Works - Assessment of Buildings - Part 2: Framework for the Assessment of Environmental Performance. CEN, Brussels.

Chandratilake, S.R., Dias, W.P.S., 2015. Ratio based indicators and continuous score functions for better assessment of building sustainability. Energy 83, 137-143. http://dx.doi.org/10.1016/j.energy.2015.02.007.

Chandratilake, S.R., Dias, W.P.S., 2013. Sustainability rating systems for buildings: comparisons and correlations. Energy 59, 22-28. http://dx.doi.org/10.1016/ j.energy.2013.07.026.

Cole, R.J., 1998. Emerging trends in building environmental assessment methods. Build. Res. Inf. 26, 3-16. http://dx.doi.org/10.1080/096132198370065.

Geissler, S., Macoun, T., 2001. Sustainability Indicators of Built Environment. CRISP, Vienna.

Guenther, R., Vittori, G., 2013. Sustainable Healthcare Architecture, second ed. John Wiley \& Sons, Inc., New Jersey.

Guenther, R., Vittori, G., 2008. Sustainable Healthcare Architecture, first ed. John 
Wiley \& Sons, Inc., New Jersey.

Haapio, A., Viitaniemi, P., 2008. A critical review of building environmental assessment tools. Environ. Impact Assess. Rev. 28, 469-482. http://dx.doi.org/ 10.1016/j.eiar.2008.01.002.

Hambali, A., Sapuan, S.M., Ismail, N., Nukman, Y., 2010. Material selection of polymeric composite automotive bumper beam using analytical hierarchy process. J. Cent. South Univ. Technol. 17, 244-256. http://dx.doi.org/10.1007/s11771-0100038-y.

Hsiao, S.-W., 2002. Concurrent design method for developing a new product. Int. J. Ind. Ergon. 41-55 http://dx.doi.org/10.1016/S0169-8141(01)00048-8.

iiSBE, 2016. Home page of iiSBE. http://www.iisbe.org (Accessed 20 November 2016).

ISO TS, 2011. ISO/TS 21929-1: 2011, Sustainability in Building Construction - Sustainability Indicators - Part 1: Framework for the Development of Indicators for Buildings. ISO, Geneva.

ISO TS, 2010. ISO/AWI 21929, Building Construction - Sustainability in Building Construction - Sustainability Indicators - Part 1-Framework for the Development of Indicators for Buildings and Core Indicators. ISO, Geneva.

Kats, G., 2003. Green building Costs and Financial Benefits. Massachusetts Technology Collaborative, Westborough.

Kurtz, J., Jackson, L., Fisher, W., 2001. Strategies for evaluating indicators based on guidelines from the Environmental Protection Agency's Office of Research and Development. Ecol. Indic. 1, 49-60. http://dx.doi.org/10.1016/S1470-160X(01) 00004-8.

Mateus, R., Bragança, L., 2012. Designing an affordable sustainable residential building block using the SBTool PTsustainability rating system. Int. J. Sustain. Build. Technol. Urban Dev. 3, 285-293. http://dx.doi.org/10.1080/ 2093761X.2012.746949.

Mateus, R., Bragança, L., 2011. Sustainability assessment and rating of buildings: developing the methodology SBToolPT-H. Build. Environ. 46, 1962-1971. http:// dx.doi.org/10.1016/j.buildenv.2011.04.023.

Pires, S.M., Fidélis, T., 2015. Local sustainability indicators in Portugal: assessing implementation and use in governance contexts. J. Clean. Prod. 86, 289-300. http://dx.doi.org/10.1016/j.jclepro.2014.08.002.
Reed, M.S., Fraser, E.D.G., Dougill, A.J., 2006. An adaptive learning process for developing and applying sustainability indicators with local communities. Ecol. Econ. 59, 406-418. http://dx.doi.org/10.1016/j.ecolecon.2005.11.008.

Roberts, G., Guenther, R., 2006. Environmental responsible hospitals. In: Marberry, S. (Ed.), Improving Healthcare with Better Building Design. Health Administration Press, Chicago, pp. 81-107.

Saaty, T.L., 2008. Decision making with the analytic hierarchy process. Serv. Sci. 1 $1-16$.

Saaty, T.L., 1988. What Is the Analytic Hierarchy Process? McGraw Hill, New York.

Sambasivan, M., Fei, N.Y., 2008. Evaluation of critical success factors of implementation of ISO 14001 using analytic hierarchy process (AHP): a case study from Malaysia. J. Clean. Prod. 16, 1424-1433. http://dx.doi.org/10.1016 j.jclepro.2007.08.003.

Shaw, C.D., Kutryba, B., Braithwaite, J., Bedlicki, M., Warunek, A., 2010. Sustainable healthcare accreditation: messages from Europe in 2009. Int. J. Qual. Health Care 22, 341-350. http://dx.doi.org/10.1093/intqhc/mzq043.

Short, C.A., Al-Maiyah, S., 2009. Design strategy for low-energy ventilation and cooling of hospitals. Build. Res. Inf. 37, 264-292. http://dx.doi.org/10.1080/ 09613210902885156

Stevanovic, M., Allacker, K., Vermeulen, S., 2016. Hospital building sustainability: the experience in using qualitative tools and steps towards the life cycle approach. In: SBE16, International Conference on Sustainable Synergies from Buildings to the Urban Scale. Thessolaniki, pp. 61-67.

Thanki, S., Govindan, K., Thakkar, J., 2016. An investigation on lean-green implementation practices in Indian SMEs using analytical hierarchy process (AHP) approach. J. Clean. Prod. 135, 284-298. http://dx.doi.org/10.1016 j.jclepro.2016.06.105.

Tsalis, A.T., Nikolaou, E.I., Grigoroudis, E., Tsagarakis, P.K., 2015. A dynamic sustainability Balanced Scorecard methodology as a navigator for exploring the dynamics and complexity of corporate sustainability strategy. Civ. Eng. Environ. Syst. 32, 281-300. http://dx.doi.org/10.1080/10286608.2015.1006129.

Yadollahi, M., Mirghasemi, M., Mohamad Zin, R., Singh, B., 2014. Architect critica challenges as a project manager in construction projects: a case study. Adv. Civ. Eng. 2014, 1-15. http://dx.doi.org/10.1109/MC.1983.1654266. 